\title{
ER KIRKELIG POLEMIK NEDBRYDENDE?
}

En diskussion mellem Grundtvig og Nic. Faber $i 1825$.

\author{
Af Kaj Baagø.
}

I sin afhandling om Grundtvigs nedlæggelse af embedet i 1826 bemærker Glædemark ${ }^{1}$ ), at vi desværre kun har få kilder til belysning af Grundtvigs personlige stilling til kirkekampen i vinteren 1825/26. Glædemark kunne dengang ikke kende et par breve, som Grundtvig sendte den senere biskop N. Faber i november/december 1825, da Fabers arkiv først senere er kommet for dagen. Det må derfor være berettiget at fremdrage dem her, da de ikke blot viser Grundtvigs reaktion på Fabers kritik af ham, men også hans syn på »Theologisk Maanedsskrift«, hans medarbejdere (navnlig Lindberg) og på den netop nu begyndte kirkekamp i det hele. Uaktuelle er de heller ikke, såvist som spørgsmålet om kirkelig polemik atter er på dagsordenen.

Nicolai Faber var født i Odense i 1789, tog teologisk embedseksamen 1811 og levede derefter en række år af undervisning og kontorarbejde. 1817 erhvervede han sig den filosofiske doktorgrad. På grund af de fortvivlede økonomiske forhold i Danmark tænkte han på at udvandre til Amerika, men opgav det dog igen og udnævntes endelig 1820 til sognepræst for Allested og Vejle på Fyn; 1826 dr. theol., 1830 stiftsprovst i Odense og fra 1834 biskop over Fyns stift. 》Hans teologiske Standpunkt var, som saa mange af hans samtidiges, ikke klart; der var en Stræben efter at vikle sig ud af hans rationalistiske Tankegang; men han og mange med ham havde ondt ved at finde et fast Punkt, hvortil deres Bestræbelser kunde knyttes« (L. Koch) ${ }^{2}$ ). Han kan forsåvidt godt regnes for en repræsentant for »overgangsteologien«, som brød frem i Danmark fra 1817, og han stod da også i forbindelse med folk som professor Jens Møller, biskop Frederik Münter, og sikkert også P. E. Müller. Han havde -

1) H. J. H. Glædemark: N. F. S. Grundtvigs Nedlæggelse af Præsteembedet i 1826. Kirkehist. Saml. 6. R., III, 269.

2) C. F. Bricka: Dansk Biografisk Lexikon, V, 6. Cf. også Bjørn Kornerup i D. B. L. VI, $509 \mathrm{ff}$. 
som han selv skriver - samme mål som Grundtvig: overvindelse af vantroen (rationalismen), men hans teologi var en ganske anden. Kristendommen var for ham den højeste religion, den højeste udvikling af det menneskelige åndsliv. Den lutherske skelnen mellem lov og evangelium, endsige den lutherske forståelse af syndens væsen var ham fremmed. Han hævdede - som det vil fremgå af det følgende - en overensstemmelse mellem fornuft og åbenbaring, men det var ganske klart, at hans fornuftbegreb var et andet og dyberegående end rationalismens og kantianismens. Fornuften var for ham (og han synes her påvirket af tysk idealisme) en guddommelig kraft i tilværelsen og i mennesket. Derfor kunde fornuften - for ham ikke være i strid med den guddommelige åbenbaring i Jesus Kristus. 》Sandheden er kun een « - den sætning stod urokkelig fast for Faber.

I Begyndelsen af 1825 udsendte han sine »Tolv Prædikener«. Han ville med dem vise middelvejen mellem rationalisme og ortodoksi. »Saa lidet som den i de sidste Decennier lærte Begrundelse af Moral og Religion kan tilfredsstille« (skrev han til Jens Møller om prædikenerne) ${ }^{3}$ ), »saa tilbøielig synes derimod Nutiden til reent at glemme det Meget, som i de sidste Decennier til Sandhedens skarpe Undersøgelse er bleven lært og fremsat, og derimod at ile ned til en dunkel Følelses Troe, hvormed sand, lys Christendom nødvendig maa forsvinde. Mellem tvende Extremer at finde og vise den sande Vei, derpaa er det, at jeg har gjort et Forsøg«.

Grundtvig anmeldte prædikenerne i »Theologisk Maanedsskrift«s Juli-nummer ${ }^{4}$ ). De var på ingen måde bibelske, skrev han. Fabers tale om fornuften som menneskets indre lys og om fornuftens og åbenbaringens overensstemmelse måtte han naturligvis forkaste. Ikke desto mindre kunne Grundtvig ikke andet end glæde sig over dem i sammenligning med, hvad tiden ellers prædikede. Faber var ingen tom eftersnakker af rationalismen; her var noget nyt; her var iver for sandheden og lyst til at bekæmpe vantroen.

»Uagtet jeg derfor aldrig kan enten ønske eller billige, at der prædikes saaledes i Christenheden, finder jeg dog, der var alt meget vundet, naar der ingensteds blev prædiket mere ubibelsk; thi deri er jeg aldeles enig med Forf., at i Grunden er og kan der kun være et eneste aandeligt Lys, nemlig Sandhedens, og hvem der da kun elsker og for Alvor søger Sandhed, kommer sikkerlig engang til, ganske anderledes end Forf. endnu, at høre Jesu Røst og troe paa Ham.«

Fabers tale mod de gudelige forsamlinger på Fyn måtte han imidlertid bestemt afvise. Han så deri samvittighedstvang, intolerance og

$\left.{ }^{3}\right)$ Faber til Jens Møller $1 / 21825$, N. k. S. $3000,4^{\circ}$, KB.

$\left.{ }^{4}\right)$ Theologisk Maanedsskrift II, 1825, 55 ff. 
papisteri. Lægfolket måtte have lov til selv at afgøre, hvad de for Gud og deres samvittighed ville tro som Guds ord og skriftens rette mening.

Det var kort efter, Grundtvig gjorde sin mageløse opdagelse, fundet som skulle give lægmanden prøvestenen for, hvad der var ret kristendom og ret skriftfortolkning: den apostoliske trosbekendelse. Endnu inden den var blevet offentlig kendt, skrev Faber et svar til Grundtvig. »Fem Breve til Hr. Pastor N. F. S. Grundtvig angaaende Fornuft, Aand og Bogstav, Andagtsforsamlinger udenfor Kirken og Muligheden af et Beviis for Guds Tilværelse. - Andet Forsøg til sand Christendoms Bestyrkelse mod Tvivl og Vildfarelser « udkom efter »Kirkens Gienmæle«, men var skrevet allerede i August 1825, hvilket forfatteren også fandt sig nødsaget til udtrykkelig at anmærke på titelbladet. Det 1. spørgsmål: »Er Fornuften en guddommelig eller menneskelig Evne?« besvarede Faber med en filosofisk redegørelse for fornuftbegrebet. Fornuften er »den Kilde, hvoraf Forstanden henter de oversandselige Begreber« (7). Derfor vidste menneskene også før åbenbaringen, hvad ordene Gud, dyd, pligt etc. betød, ligesom bibelen jo heller ikke kan forstås og opfattes uden fornuften. Fornuft og åbenbaring strider ikke mod hinanden, men åbenbaringen er nødvendig for at mennesket 》hastigere« kan nå frem mod det højere (22). - Det 2. spørgsmål: „Skal Christendommen fremmes ved Aanden eller Bogstaven? « (32 ff.) var et angreb på den argumentation, 》Theologisk Maanedsskrift« anvendte. Man skal ikke fordre blind bogstavtro af mennesker; kristendommen fremtræder jo ikke som noget mennesket fremmed, men troen er en udfoldelse af den mennesket iboende ånd. (Han forkaster kantianismen). Troen betyder ikke disharmoni, men tværtimod harmoni i tilværelsesforståelsen. Det 3. og 4. brev handlede om problemet: Kan sand Christendom ventes fremmet $i$ religiøse Forsamlinger udenfor Kirken og ved uddannede Lærere? (59 ff.). Han tilbageviste har Grundtvigs »ensidighed«, - tendensen til at skære alle præster over een kam og skildre den åndelige situation i landet, som om lægfolket ikke havde nogen mulighed for at få deres religiøse »trang« tilfredsstillet undtagen udenfor kirken. Ligeledes afvistes påberåbelsen af samvittighedsfrihed. Staten havde truffet sunde foranstaltninger til kristendommens fremme ved at uddanne præster videnskabeligt og ordne gudsdyrkelsen på en sund måde. Den kunne derfor ikke roligt se på, at fanatisme og sværmeri udbredtes gennem andagtsforsamlingerne. I disse, hævder Faber, forkyndes helvedes ild, den menneskelige naturs fuldstændige fordærvethed, kundskab og lærdom foragtes og sværmeriet næres; (»Een skjælver, en Anden gynger frem og tilbage, en Tredie gisper, fordi, som 
det paastaaes, Hjertet springer i Livet af Glæde over at høre Guds Ord, en Fjerde føler Aandens Bevægelse i sit Liv, hvor den foraarsager en Gylpen eller Ræben, som efterlader en liflig Smag ...«(87)). Det stod fast for Faber, at kun i kirken og kun gennem den uddannede præsts skriftfortolkning kan sand og sund opbyggelse nås. Det 5. brev hed »Om Muligheden af et Beviis for Guds Tilværelse" og refererede til Grundtvigs afhandling »Om Natur og Aabenbaring«, hvor denne i sin kritik af Kant havde søgt i en vis forstand at fastholde det kosmologiske og ontologiske Gudsbevis ${ }^{5}$ ). Faber afviste dette. Et bevis kan kun nås ved slutning ud fra en sandhed, som står ubetinget fast (Grundtvigs havde hævdet »selvbevidstheden« som urokkelig sandhed). Men der er ingen sandhed udenfor den evige sandhed, dvs. Gud. Først må Guds tilværelse sættes som betingelse for, at sandhed er til; sandheden er kun een. Altså kan det ikke bevises, at Gud er til; Grundtvig farer altså med løgn! - Til slut fulgte et »alvorsord《 til Grundtvig, - en advarsel mod at fortsætte med sine hårde, blinde og ensidige domme og en opfordring til at vise brodersind mod sine embedsbrødre.

Af de moderate teologer blev bogen hilst velkommen; navnlig biskop Münter var begejstret. Til sammenligning med Grundtvigs bedømmelse af bogen skal her bringes et citat fra Münters brev til Faber:

»Jeg har læst Deres Velærværdigheds Breve til Gr. med megen Fornøielse. Det er sande og kraftige Ord, De har sagt ham i et værdigt Sprog. Han vil faae ondt ved at svare, hvis han ellers svarer; thi jeg ved ikke hvad han skal sige, uden at ogsaa De hører til det Partie, han saa ivrig strider imod! Men hvad der neppe vil virke paa ham, vil sikkert virke paa endeel af de billigere blant hans Venner, det vil virke paa mange andre, og befæste dem i liberalere Anskuelser - og saaledes vil Deres Arbeide ei være uden Velsignelse. Det er en underlig Tid vi lever $i$, men det har vi jo ofte erfaret, at Extremerne berøre hinanden, og at det varer længe inden Propidikalen (?) atter bevæger sig med Rolighed og Orden. Sand christelig Oplysning vil ikke fortrænges ved Enthusiasters Bestræbelser, og Enthusiasmens Natur fører det med sig, at den, ligesom Feber, omsider hører op, naar rigtige Lægemidler anvendes, og disse er jo her sund Fornuft og rigtig Religionskundskab.

Maaske Processen ${ }^{6}$ ) Gr. har at føre ogsaa vil bidrage til at afkøle ham. Hans Advokats Paastand, at Retten skal afvise Sagen som sig uvedkommende, vil neppe finde deres Approbation; og han maa dog efterhaanden indsee at hans Anke mod Cl.(ausen) er ugrundet, ihvorvel der kan være adskilligt at indvende mod, og med rette at dadle i $\mathrm{Cl}$. Yttringer. Kuns er det høiligen at beklage at denne Strid er bleven en Sag der interesserer Almuen, og at saa manges Mistanke er vakt mod den akademiske Underviisning $\left.\ll^{7}\right)$.

5) Theologisk Maanedsskrift II, 1825, $23 \mathrm{ff}$.

6) Nemlig injurieprocessen mellem H. N. Clausen og Grundtvig.

$\left.{ }^{7}\right)$ Münter til Faber ${ }^{10 / 12} 1825$. N. k. S. 2299, $2^{\circ}$, KB. 
Grundtvig svarede aldrig offentligt på Fabers »Fem Breve«. Derimod anmeldte $A$. G. Rudelbach dem lærdt og grundigt i »Theologisk Maanedsskrift«s Maj-nummer 1826 (V, 127 ff.). Samme år angreb også en søn af fung. biskop Stockholm i Aalborg, cand. theol. P. W. Stockholm, Fabers ytringer om fornuften ${ }^{8}$ ). - Allerede 1827 foer Faber ud mod Grundtvig igen, dennegang i anledning af hans nye syn på den apostolske trosbekendelse ${ }^{9}$ ), og senere kom det til sammenstød mellem Lindberg og Faber.

\section{$\left.\mathrm{I}^{10}\right)$}

\section{Hr. Doctor Faber!}

Selv efter at have læst alle Deres fem uhøflige Breve til mig, og det Sjette ${ }^{10 a}$ ) med, fortryder jeg intet Øieblik at have bedømt Deres Prædikener saa hæderlig og saa broderlig, som paa nogen Maade var mig muligt, uden at dølge eller modsige min Overbevisning i Salighedens Sag, som skal være mig dyrebarere end baade Fader og Moder, Syster, Broder og Alt hvad der ellers har lovligt Krav paa min Kiærlighed; De derimod er bange for at have tiltalt og omtalt mig for mildt og venligt, uagtet Gud veed, at Broder-Navnet i Deres Breve kun har lidt at betyde, og bliver omsider, hvor De behandler mig som en Skovisk, og lader mig for lutter Løier, fare med Løgn, til den bittreste Ironie. Jeg anseer Dem endnu i dette Øieblik for en Mand, det alvorlig er om Sandhed at giøre, og hvi skulde jeg ellers skrive Dem til, og det blot fordi jeg selv i Deres Breve under den uhyre skiæve Bedømmelse baade af min videnskabelige Synsmaade, min Christendom og mit Sindelag finder, ligesom i Prædikenerne en varm, ærlig Grund-Tone, som tiltaler og behager mig, da jeg anseer den for Pant paa Sandheds-Kiærlighed, som i mine Øine overveier alt Andet; De derimod vakler stærkt $i$ Troen paa, at der er noget Høiere end en ussel forfængelig Argierrighed der driver mig, og dog har jeg en 20 Aars SkribentBane bag mig, paa hvilken det er aabenbart, jeg har // (1v) (har) gaaet den modsatte Vei end den, selv et Kiød-Hoved kunde see, førde til Læse-Verdenens Bifald og hvad man kaldte literair Fre.

Indseer De ikke, at af os To, er jeg for Øieblikket den billige Dommer, og De, som i de haardeste Udtryk bebreider mig Ubillighed, den saare ubillige, da har vi ikke meer med hinanden at tale, og De maa da aldrig tænke, jeg indlader mig i nogen Penne-Strid med Dem; thi de ældre Boglærde i Danmark har jeg vel stundom forsvaret mig imod, skiøndt jeg tiltaltes som en uartig, dum vankundig Pog, men de yngre Boglærde maae ikke tro, jeg paa

8) 》Vi ere Mennesker, ikke Guder«, Randers 1826.

9) 》Har Troesbekjendelsen Eneret til at bestemme, hvad der er sand Christendom og ægte christeligt?«, Odense 1827.

${ }^{10}$ ) Brevene fra Grundtvig til Faber findes i N. Fabers arkiv, N. k. S. 2299, $2^{\circ}, \mathrm{KB}$.

$\left.{ }^{10 a}\right)$ Hvad Gr. mener med det 6. brev vides ikke; Grundtvigarkivet indeholder ikke noget brev fra Faber af tidl. dato end det følgende. 
samme Betingelser indlader mig med dem. Jeg hører nu engang, ogsaa uden for Danmark, til Danmarks navnkundige Skribenter, og om det er med Ret eller Uret, overlader jeg rolig til Efterslægtens Bedømmelse, som ikke kan ignorere mig i Danmarks Litterair-Historie, og naar da en optrædende Skribent, som De i Deres Breve, tiltaler mig, som jeg aldrig vilde tiltale Dem, og det, uagtet jeg har omtalt Dem med al den Agtelse og Roes, De, uden megen Stolthed, af mig kunde vente, ja, naar De, enten ignorerende min SkribentBane, eller ubekiendt med den, rask bryder Staven over min videnskabelige Synsmaade, som selvmodsigende aandløst Vrævl, da maa De dog indsee, det er for galt. Havde De, istedenfor at bestride min historiske Beskuelse af det attende Aarhundrede ${ }^{11}$ ) og min historisk-philosophiske Tanke-Gang, som De desuden kiender saa slet, at De som oftest tillægger mig en Synsmaade, jeg paa min hele Bane har bestridt, havde De $\mathrm{i}$ densted (sic!) reentud angrebet min christelige Tro eller det theologiske System, jeg vedkiender mig, da var det en anden Sag, da // (2r) var det ikke med Skribenten, men med Præsten De havde at giøre, og som Præst maa jeg ikke holde mig for god til at strides med Nogen, naar jeg troer, det behøves; som Skribent derimod maa jeg ikke spilde min Tid paa at bestride en Vankundighed eller aandelig Blindhed, som jeg dog ikke kan helbrede, og som allerdaarligst bekæmpes med StridsSkrifter, hvor det Personlige næsten altid i det mindste for Læseren, faaer Overhaand.

Anseer De mig virkelig for en saadan videnskabelig Lilleput, som De med Deres lille Finger kan støde omkuld, og hos hvem det er en formastelig Tro, at de fleste baade jævnaldrende og yngre Præster, gierne, uden Skam kunde være bekiendt at lære lidt af ham, da vil dette Brev naturligvis forekomme Dem ligesaa uhyre latterligt, som mageløs hovmodigt; men netop den Omstændighed, at De troer, $i$ Deres Breve at have vist mig meer Agtelse, end jeg vel fortjende, giør, at jeg troer, De maa have meent det meget bedre med mig, end Ordene falde, og da det, for Skribenten Grundtvig, enten han saa er stor eller lille, for Øieblikket ei vil sige stort, hvad Præsten i Allested tænker og skriver om ham, er dette Brev en Erfarings-Prøve paa psychologiske Formodninger, jeg som Christen følde mig drevet, og, efter Deres Tiltale, berettiget til at giøre! Mueligt dog, De derved lader Dem bevæge til, naar De mener, jeg har sagt en stor Dumhed, som ikke staaer i Bibelen, dog først at læse efter og tænke over endnu engang, før De dømmer, ja mueligt endog, skiøndt Haabet synes dristigt, at Brevet kunde blive Indledning til et nøiere, venskabeligt Bekiendtskab, som jeg ikke troer vor Uenighed i Grunden er stor nok til at udelukke, og det skulde være mig meget kiært, da jeg hos ingen efter mig optraadt dansk Skribent har fundet Saameget af det ligefremme Væsen, den Kraft og Djærvhed, jeg fortrinlig, maaske endog lidt formeget ynder. Skriver.

Rolig for mine Hensigter, baade som Præst, Skribent, og dette Brevs Ærb. N. F. S. Grundtvig.

\section{S. T. Hr. Doctor philosophiæ N. Faber, Sogne-Præst i Allested ved Faaborg.}

11) Faber byggede navnlig sin kritik på Grundtvigs afhandling »Natur og Aabenbaring«, Theologisk Maanedsskrift II, 1825, $1 \mathrm{ff}, 97 \mathrm{ff}$, og $201 \mathrm{ff}$, men havde vel også afhandlingen $\mathrm{Om}$ det attende Aarhundredes Oplysning i Salighedens Sag i tankerne (s. tidsskrift I, 1825, $17 \mathrm{ff}$ og $97 \mathrm{ff}$ ). 
II.

Allested 29. Nov. $\left.1825^{12}\right)$.

Hr. Pastor Grundtvig.

Ligesom De i Deres Brev af 17. Nov. vidner selv, hvad jeg aldrig har tvivlet om, at De mener det ærligt med Sandhed, og at den har noget mere at sige for Dem end Hævdelsen af eget Navn og Ere, saaledes har jeg ogsaa det Haab, siden den samme Iver rører sig i mit Indre, at der trods alle forskellige individuelle Anskuelser maa være et fælleds Foreningspunkt for vore Hjerter, naar vi med Rolighed og Frlighed ville søge at finde det. ...... Først vil jeg da sige Dem min Mening om Deres i mangen Henseende hæderlige Dom om mine Prædikener, hvilken Mening ei gjælder denne mere end hver anden Recensents Dom. Jeg mener, at den retskafne Mand ei vil rose Andet, end hvad der fortjener Roes og ei dadle Andet end hvad fortjener Dadel ... Jeg troer derfor, at Tak til en Recensent, som blot aldeles strengt havde holdt sig til Sandhed er en Fornærmelse. Thi at følge Sandhed er Pligt; derfor skal man agtes, ikke takkes //*) Havde jeg været befængt med den Svaghed at sætte mit Navns Ere høiere end Sandhedens Værd, da havde jeg maaskee formedelst hiin Recension bleven en Lovtaler over Dem, og Deres ivrige Forsvarer; men just fordi Sandhed er mig mere end mit Navn, just fordi jeg nærede Agtelse for Deres Tænkemaade i det Hele, derfor kunde Deres hæderlige Dom ikke være den mindste Bevæggrund til at lade Paastande staae urørte, fordi Deres Navn stod derunder. Paa den anden Side var det heller ingenlunde denne smaalige, let pirrelige egoistiske Tænkemaade, der drev mig, ifølge hvilken Mennesket saa ofte mener at maatte til sidste Aandedræt hævde, hvad han eengang har sagt, blot fordi han nu eengang har sagt det; thi ogsaa her fremtræder Misforholdet imellem det egne Navn og Sandheden. Fra denne Synspunct betragtet vil De selv see, at den billige og hæderlige Dom over mine Prædikener ligesaalidet kunde eller burde bevæge mig til at tie, som paa den anden Side Bevæggrunden til at tale heller ingenlunde ligger $\mathbf{i}$ Recensionens ufordelagtige Dom; thi jeg vilde $i$ ethvert Tilfælde have fremtraadt; Deres Recension gav ligesom sidste Stød til at Beslutningen, der udsprang af andre og høiere Bevæggrunde, virkelig udførtes. ......//

Saa vist altsaa som det Høie og Sande taler gjennem mangt et Skrift fra Deres Haand, vil ogsaa Deres Navn i denne Henseende stedse blive hæderligt, fordi Sandhedens Aand gaaer gjennem alle Secler til alle Secler og har det sande universelle Sprog, der forstaaes af alle gode Hjerter; men umuligt kan De derfor troe, at Bevæggrunden til mine 5 Breve skulde ligge i en hemmelig Lyst til at give et agtet Navn et Sidestød; thi skjøndt kun lidt over 36 Aar, takker jeg dog min Gud for, at han har opladt mit Øie saaledes for Sandhed, at saadanne smaalige Hensigter ved hans evige Bistand ei skulde faae Magt over min Pen. ....// De berører dernæest, at det var en anden Sag, om jeg havde angrebet Dem som Præst i Deres christelige Troe, i Deres theolog(iske) Synsmaade; da vilde De hævde denne; men at det forholder sig anderledes med Deres historisk philosophiske Anskuelser. I mine Tanker og efter min fuldeste Overbeviisning gjør De her en Distinction, som ikke kan bestaae; thi da Sandheden kun kan være een, maa hos hver tænkende

${ }^{12}$ ) Brevet i Grundtvig-arkivet, fasc. 412, KB. Gengives her med enkelte overspringelser.

*) // betyder ny side. 
Præst Theologie og Philosophie enten være smeltede sammen til eet, eller den Sidste reent fordrevet; og hvor Præsten dømmer, maa hans Maalestok være hans theolog(iske) System og altsaa han selv som Præst angribes, med mindre han vil gjøre 2 Personer af sig selv, og som Skribent have Lov til at tale paa een Maade, som Præst paa en anden. Da nu mine Breve gaae ud fra Deres Synspuncter, yttrede $\mathrm{i}$ det theolog(iske) Maanedsskrift, og De her maa ansees at have talet som Præst, saa angaae mine Breve ogsaa Dem allene som Præst, ei som Skribent; og Deres Spørgsmaal maatte snarere være, hvorfor jeg har angrebet Dem fra den philosophiske, og ikke fra den reenbibelske Side; og i denne Anledning skal jeg ogsaa give Dem mit oprigtige Svar.

Det er ingenlunde skeet, fordi Deres Standpunkt her var urokkeligt, nei, som ærlig Mand forsikkrer jeg Dem, at en Seir her var meget let; men Sagen kunde paa dette Gebeet ikke føres uden Forargelse, derfor lod jeg den Side saa meget muligt uberørt; thi hvad vilde Følgen være bleven anden end den, at jeg ved den samme Bibels Ord, som De støtter Dem til, havde forsvaret Sætninger, Deres aldeles modsatte; og da dette, hvilket umuligt kan være skjult for Deres Øie, naar De vil betænke og besinde Dem, er meget gjørligt, saa vilde jeg, ved at føre Striden paa dette Gebeet, have givet den Letsindige Anledning til fuldkomment at forsvare sin Vantroe, naar selv Kirkens Lærer med Bibelen i Haanden kunne driste sig til at forsvare Begreber, der ere hinanden modsatte, saa at Enhver nu med Føie kunde spørge: ja hvad er nu Ret, hvad Uret, hvad er Sandhed, hvad er Løgn? ... // ... En Seir, kjøbt med en saadan Forargelse, vilde, med Hensyn paa sand Christendoms Stadfæstelse, være altfor dyrekjøbt, og derfor havde jeg ikke Hjerte til at vinde den; men hvis det theolog(iske) Maanedsskrift vedbliver i den Fortolkningsmaade, som det har begyndt, og hvorom jeg nærmere skal tale siden, saa forudseer jeg, at der maa komme den, der, med mindre religiøst Sind, vil føre Kampen ind paa Bibelens eget Gebeet, og i Sandhed uden megen Møie rokke mange af de hidtil fremsatte Paastande, til megen Forargelse for hver Christen, der i Guds Ord seer sin Støtte; og Skylden kan da ikke tørne mere paa den, der fører Kampen paa denne Maade, end paa den, som udaskede hertil.

Efter saaledes at have besvaret Deres Brev maa jeg gjøre Deres Ord til mine, og oprigtigt og hjerteligt ønske, at en Indledning her maatte kunne gjøres til et nøiere og venskabeligt Bekjendtskab, som selv da, om vore Anskuelser ikke kunne forenes, om vi endog arbeide paa forskjellige Maader, maatte overbevise os indbyrdes om, at det i Grunden dog er det samme Maal, vi stride for, og saaledes, uagtet individuel Forskjellighed, vinde og sikkre os hinandens gjensidige Agtelse og Velvillighed.

$\mathrm{Og}$ det Foreningspunct, hvori vi efter mit $\mathrm{Haab}$ og min Overbevisning, støde sammen, er den levende Følelse af noget Høiere end dette Jordelivs smaalige Syslen; den levende Erkjendelse af den Høiestes Styrelse gjennem Jordelivet, stadfæstet ved hver Tids Erfaring. I Forbindelse hermed en dyb Følelse af, hvorlidet dette Jordelivets høiere Øiemed erkjendes deels af Mskt. (Mennesket) i Almindeligh(ed), deels af Religionens Lærere for en stor Deel; en Sorg over, at Christend. (Christendommen) saaledes har tabt sin sande Betydning i Almeenlivet, Sorg over, at den paa den uforsvarligste Maade omgaaes // af mange dens Lærere selv; at saaledes Verdens Sands har faaet en Overmagt over den bedre Aand, og Vantroe findes udbredt gjennem alle Stænder, selv findes hos dem, der skulde stræbe at bekjæmpe den. Heri troer jeg, at vi ere enige; men strax i Angivelsen af Grunden til denne Vantroe 
mener jeg ogsaa, at vi adskille os; thi efter det theolog(iske) Maanedsskrift at slutte, da er Deres Tanke den, at fordi det Positive i Christendommen er bleven rokket ved profane Tvivl, derfor har Vantroens Aand udbredt sig overalt; jeg derimod troer lige det Modsatte, at just fordi Vantroens Aand /: ifølge hvilken alt Høiere ansees for tomme Begreber :/ udbreder sig i Hjerterne, derfor fulgte naturligvis Vantroe i Henseende til Christendommen. Atter forene vi os i det inderlige Ønske, at det med Christendom, dens Forkyndelse og Modtagelse med Sagtmodighed maatte snart blive anderledes og bedre. Men atter adskille vi os igjen i Maaden og Veien til at bevirke dette, og det naturligvis overensstemmende med vor forskjellige Synspunkt af Vantroens Grund. Det theo$\log ($ iske) Maanedsskrift gaaer ud paa at paastaae de positive Dogmers Erkjendelse uden nogen Betingelse, og mener saaledes at gjenvinde Christend(ommen) sin Anseelse, jeg derimod mener, at Veien er den at vække Aanden og den levende Agtelse og Erkjendelse af det Høieres fulde Realitet, hvoraf Troe paa Forsyn og dets Aabenbarelse i Christend(ommen) vil være en nødvendig Følge. Maalet synes for os begge det samme, men Maaden aldeles modsat; nu er det ingenlunde ligegyldigt ad hvilken Vei man gaaer; deels opnaaes Maalet ikke lige let ved hver Vei; deels gjør virkelig meget ofte Valget af den urette Maade, at man, i Bevidstheden af sin gode Hensigt, troer sig berettiget til Skridt, som skade mere end gavne. ........ At sige ham (den vantro), »det skal du troe er kun at udsætte sig for hans Haan; men røres først hans Hjerte, da spotter han ikke mere, thi allerede rører der sig da Noget, som gjør, at han uvilkaarlig undseer sig ved sin Spot; at tilraabe ham »dette er Sandhed; det skal Du uden videre troe«, det er kun at forhærde ham i hans Blindhed; thi han underkaster sig ikke et saadant Magtsprog; men at aabne hans Aands Øie først, det løser Hjertets Forhærdelse, og bevæger ham til at annamme Sandheden med Sagtmodighed; og medens den første Fremgangsmaade, der saa at sige farer frem med Skjænd og Band og Fordømmelse som en Boreas ${ }^{13}$ ) Storm ufeilbarlig bevirker, at Mennesket end mere forhærdet knapper Vantroens Kjortel fastere om sig, saaledes vil den modsatte Fremgangsmaade som en blid Foraarssoel gjøre det lyst $\mathbf{i}$ hans Hjerte og saaledes opvarme det, at han frivilligen kaster Vantroens Klædning fra sig.

At nu Aanden ei altid ved Sagtmodighed vækkes, men ofte fordrer Djærvhed i Tale, det er en Sag, jeg fuldeligen veed og erkjender, og har nogen med Kraft og Djærvhed erklæret Last og Udyder Krig, talt saaledes til Hjerterne, at de rystedes og bævede, saa tør jeg maaskee ogsaa regne mig iblandt disses Tal, men herved bekjæmpede jeg blot Sløvhedens, Vantroens, Verdens Aand, med Blidhed traadte da Xi (Christi) Ord frem, og det tør jeg ingenlunde tvivle om, at de af mangt Hjerte da annammedes med Sagtmodighed. Og her troer jeg da at have viist baade Eenheden og Uenigheden mellem os. Da Maaden at fremme Cristendommen paa ingenlunde er uvæsentlig, saa er jeg virkelig af den Mening, at Uoverensstemmelsen mellem os ikke blot angaar noget uvæsentligt, men virkelig noget Væsentligt; men da Maalet (vist nok), efter min Mening, for os begge er det samme, saa vil vist nok Enhver ad sin Vei stræbe at fremme sin Hensigt, og af mit inderste Hjerte ønsker // jeg, at Øiemedet maatte naaes. Men hvis mit Ord, mit Haab kunde formaae Noget, da skulde det være dette, at dog Fremgangsmaaden i Noget maatte forandres, da jeg virkeligt er inderlig overbeviist om, at det fælleds gode Maal derved lettere vilde fremmes; og $\mathrm{i}$ denne Tanke er det, at jeg nu til Slutning frem-

13) Det græske navn for nordenvinden og nordenvindens Gud. 
sætter Bemærkninger i Anledning af $\mathrm{Hr}$. Adjunct Lindbergs ${ }^{14}$ ) Oversigt etc. i theolog(isk) Maanedsskrift for November, hvorved min forrige Synsmaade vil endnu fremtræde $i$ et klarere Lys. Naturligvis er det Følgende fremsat uden den mindste Animositet og virkelig i den eneste Hensigt om muligt at bidrage Noget til, at Sandhed og sand Christendom virkelig kunde fremmes og faae Indgang i Hjerterne.

Faber angriber derefter Lindbergs artikel ${ }^{15}$ ) under elleve punkter.

1. Den er et Stridsskrift og derfor efter både hans og Grundtvigs mening uegnet til at fremme sandhed.

2. Alt er lagt an på at nedrive og intet sættes i stedet.

3. Artiklen er ildesindet og gør modstanderne foragtede og latterlige.

4. Uredeligt mod andre fortolkere at vælge Hornemann som repræsentant for G.T.-studiet (»thi det kan jeg dog forsikkre, at i mine Studenter-Aar og længe efter var der om hans christelige philosophiske Foredrag kun een Stemme, og med Undtagelse af 2 à 3 saakaldte Collegieheste, der formedelst deres gyselige Udholdenhed haabede en Slags Examensbarmhjertighed, ved jeg virkelig Ingen, der med Stadighed besøgte hans Forelæsninger $\ll)$.

5. Hvorfra ved Lindberg, at G. T.-forskerne $\mathrm{i}$ det 18 . årh. ville nedrive bibelens autoritet og ikke blot blev forledt af tidsalderens ånd ? ${ }^{16}$ )

14) Jacob Christian Lindberg, der var medarbejder ved sTheologisk Maanedsskrift« fra begyndelsen. Han tog teologisk embedseksamen i januar 1822 med karakteren »Laudabilis præ ceteris et quidem in primis egregie«. November s. å. ansattes han som adjunkt ved Metropolitanskolen i København, udgav bl. a. den første hebraiske grammatik herhjemme, som byggede på Gesenius og arbejdede iøvrigt (sammen med biskop Münter) med numismatiske studier. Det var A. G. Rudelbach (se nedenfor), som fik ham med ind i kredsen bag »Theologisk Maanedsskrift«.

15) »Oversigt over den Skjebne, som det Hebraiske Sprogstudium og det gamle Testamentes Fortolkning har haft i Danmark i Aarene 1790-1820«, Theologisk Maanedsskrift 1825, I, $40 \mathrm{ff}$. og $128 \mathrm{ff} .$, - III, $119 \mathrm{ff}$. (altså april, maj og novemberhæfterne; den lange pause skyldtes sikkert, at Rudelbachs anmeldelse af $\mathrm{H}$. N. Clausens bekendte skrift »Catholicismens og Protestantismens Kirkeforfatning, Lære og Ritus skulle ud hurtigt). De to første stykker er en kritik af de foreliggende hebraiske grammatiker, navnlig var omtalen af prof. $J$. Rasmussens en fuldstændig »nedsabling«, som vakte megen opsigt. (Da Rasmussen i marts 1826 begik selvmord, sagde man, at Lindberg havde drevet ham i døden, - en »sladder«, som fulgte Lindberg hele livet. Han døde i delirium tremens). - Det tredie stykke, som Faber særligt refererer til, er en oversigt over GT-fortolkningen og væsentligt en voldsom og bidende ironisk kritik af rationalistiske forskere i Tyskland og prof. Hornemann. Det var formet som en tale af en rationalistisk ekseget om det gamle testamente og harcellerer over de mange tåbeligheder, som det 18. århundredes GT-forskere havde udgivet for videnskab. Men det må indrømmes, at Lindberg havde fundet de værste eksempler frem, og at de repræsentanter, han valgte blandt GT-forskerne, i 1825 af de fleste blev betragtet med et skuldertræk. Lindbergs positive syn på GT kom kun - meget kort udtrykt - frem i indledningen.

16) Cf. Theologisk Maanedsskrift III, 120: Forskerne har ikke æret og agtet GT, fordi det er Guds ord, »men fordi det syntes dem, at det kunde være 
6. Hvordan vindes sandhed ved at personer fordømmes?

7. Hvad vindes der ved at sige $\gg \mathrm{Nu}$ har Poul og Peer nægtet Arvesynd: følgelig er han en Ikke Xen (Ikke-kristen), en Tyrk, en Hedning?? ${ }^{17}$ )

8. Hvorledes kan man sidestille G.T. med N.T.?? »vil man gjøre os til jødiske Christne eller Christne Jøder?«, igen pålægge et åg, Jesus og apostlene fritog os for ${ }^{18}$ ).

9. Tillægger man ikke »den dogmatiske Ring«, som opstilles, større betydning end Jesu egne ord.

10. Ved Lindbergs polemiske og personlige tone bliver sandhed ikke opbygget.

11. Man skal gå frem sindigt og betænksomt og beskedent, når det gælder kamp for sandheden, og ikke »med søndertrædende Fod fare ... frem over Fortid og Nutid, menende at føre $i$ vor Haand allene det Sandhedens Banner, som Alle skulle følge«. Man skal opbygge - ikke skabe anarki. Men i 》Theologisk Maanedsskrift« har man nedbrudt præsternes agtelse $\mathbf{i}$ menigheden: $\gg . .$. i pietistiske Forsamlinger er det nok at en Præst har sagt ... Noget, for at smile ad det, og ikke sjeldent søges der en Fre i at fortælle, hvorledes man har svaret denne Præst, drevet hiin til Vands«. Det teologiske fakultets anseelse er undergravet. »Horne$\operatorname{mann}^{19}$ ) og Clausen ${ }^{20}$ ) ere saaledes affærdigede paa en Maade, der tilsidesætter den Agtelse, man er Mænd af den Dannelse og paa denne Post skyldig; da Prof. J. Møller exegetiserer over det gl. T. skal han sagtens nu med; og efter de Vink om Fornuftighed, som Hr. Dr. Rudelbach $^{21}$ ) giver i Nov. Heftet, kommer vel ogsaa Touren til Prof. P. E. Müller. Naar nu da al Tillid til det theolog(iske) Facultet og Danmarks fra dem udgangne Lærere er nedrevet; naar Studerende og Lægfolk ifølge heraf ei kunne finde Trøst el. Belærelse i (vort) deres Foredrag forme$\mathrm{d}(\mathrm{elst})$ den vakte Mistillid; hvor skal de da nu henvende sig? Troer da nu det theol. M.(aanedsskrifts) Forfattere, at de som et Centrallys kunne allene // udbrede den nødvendige Oplysning i hele Landet? Kunne de, selv om de dannede Larere efter deres Sind, mere sikkre disse den Agtelse, de nu selv i Bund og Grund nedbryde? I Sandhed jeg forsikkrer Dem, at paa den Maade, der nu gaaes frem, nedbrydes det Ene med det Andet, og ved Omstyrtningen af Lærerstandens Agtelse bliver Følgen Anarki, ingenlunde Sandhedens rene Forfremmelse; og det er høi Tid, at man klart tydeliggjør sig Følgerne af hiin Fremgangsmaade, og forandrer den saaledes, at Sandheden kan vinde, uden at alle ærværdige Forhold skulle rystes. Hvis ikke hver Lærer i sin Kreds virker med Aand

en beqvem Bog til at drive al Slags Uvæsen med, og saaledes ryste Christendommen i dens Grundvold«.

$\left.{ }^{17}\right)$ a. s. p. $133 \mathrm{ff}$., hvor rationalisternes behandling af syndefaldsberetningen refereres.

${ }^{18)}$ a. s. p. $120 \mathrm{f}$.

19) Foruden Lindberg havde også J. A. L. Holm og A. G. Rudelbach (cf. dette hæfte pag. $39 \mathrm{f}$.) angrebet Hornemann i »Theologisk Maanedsskrift«s hæfter fra foråret og sommeren 1825.

$\left.{ }^{20}\right)$ Sigter til »Kirkens Gienmæle«.

21) Om A. G. Rudelbach se dette hæfte p. 40. Turen kom iøvrigt til P. E. Müller i 1827, da Rudelbach kritiserede dennes System i den christelige Dogmatik« (1826) sønder og sammen. Theol. Mdsskr. IX, 1827, $63 \mathrm{ff}$. 
og Hjerte, da skal i Sandhed Enkeltes Iver lidet gavne; men for at selv den nidkjære Lærer kan virke, skal hans Anseelse ei svækkes, men bevares, og formed(elst) enkelte, ja selv mange Læreres Slethed, nu at gaae frem paa en Maade, hvorved Baandet løses mellem Lærer og Menighed er uforsvarligt, uberegneligt i sine sørgelige Følger, og en Følge ikke af sindig Betænksomhed $\mathrm{i}$ at lede det Hele frem til Sandheds Erkjendelse, men af lidenskabelig Bitterhed, som, uagtet oprunden af en ædel Harme, dog iblinde og for Fode slaaer ned med Troens Sværd, og, kastende Faklen paa Vantroens Baal, antænder en Ild, den siden ei formaaer at standse; og over hvis fortærende Ødelæggelse den, naar Sindigheden vender tilbage, selv skal komme til at forbauses«.

Faber slutter med to ønsker: 1) at Maanedsskriftet vil holde op med negativt at rive ned og $\mathrm{i}$ stedet undersøge redeligt og retfærdigt, hvad der er sandhed, 2) holde op med at ødelægge præsternes og det teol. fakultets anseelse, og navnlig ville det smerte ham, om prof. P. E. Müller blev angrebet.

III.

Christianshavn, 6te December 1825.

Medtjener i Ordet og Lærdommen!

Med sand Fornøielse har jeg modtaget Deres Brev, som et Beviis paa, at De i Grunden ikke misforstod mit, og som en Bekræftelse paa min Formodning, at De, hvordan end Deres Ord lød, dog i Grunden troede, det var mig om andet end min smule Person, er mig om Sandhed og Menneske-Vel at giøre. Denne Tro til hinanden er Betingelsen for al venlig Samtale om Sandhed, og som en saadan maatte jeg ved mit første Brev lægge Vægt paa den; men nu er den en Forudsætning mellem os, som ikke bliver videre at omtale, medmindre vi fristes til Tvivl.

I det Enkelte har De ganske misforstaaet mig, som om jeg meende, De skyldte mig Tak for skaansom Behandling; thi vel takker jeg af inderste Hjerte især dem der er uenige med mig, naar de desuagtet betragte og behandle mig venlig, takker ogsaa Dem for den Betragtning i Deres Brev, skiøndt det er en almindelig Menneske-Pligt; men De vil, ved igien at læse mit Brev, see, at Paralelen jeg drog mellem Anmeldelsen af Deres Prædikener, og Deres fem Breve til mig, blot skulde vise, at De, som bebreidede mig Ubillighed og Ukiærlighed, havde ved den fiendtlige Tone i Deres Breve, sammenlignet med den venlige i min Anmeldelse, fulgt en modsat Regel af den, De gav mig, og som jeg i det mindste ikke mod Dem havde overtraadt.

De misforstaaer mig ogsaa, naar De mener, jeg af Storagtighed, der kommer af Alder, Navn, eller hvad den vil, ikke vil indlade mig i den Strid, hvortil De udæsker, thi jeg siger kun, at naar de yngre tiltale mig $i$ en foragtelig Tone, da svarer jeg dem ikke, med mindre det, for Christendommens Skyld skulde være min Præste-Pligt. De mener vel, at jeg ligesaa fuldt maatte ændse et Angreb paa min historiske og philosophiske Beskuelse, som paa min Tro og Theologie, fordi de $i$ et ordentligt Hoved nødvendig maa hænge sammen, men, uden her at ville strides om, hvem af os der har Ret, vil jeg blot vise at det hverken er en uredelig eller tom og ørkesløs Distinction jeg her giør mellem Præsten og Skribenten. Den christelige Tro er nemlig efter min ful- 
deste Overbeviisning, eens for Læg og Lærd, // (1 v) og en Saligheds-Sag for os alle, saa Angreb paa den, der i en eller anden Henseende synes mig farligt, skal jeg, som Præst, altid ændse, og, efter Evne, nedslaae. Erkiendelsen derimod er, efter sin og vor Natur, nødvendig i Grad høist forskiellig, og kun hvor den nærmest udspringer af Troen og staaer i uadskillelig Sammenhæng dermed, som i den christelige Lære-Bygning, kun der har den ubetinget Vigtighed (om Ordet ubetinget vil vi ikke trættes) i Menigheden; og saasnart vi komme derudenfor, og spørge om den menneskelige Naturs og Historiens Forhold til Christendommen, da er vi aabenbar paa de Lærdes Gebet, hvor Menigheden ikke kan følge os, og hvor det ligesaavel er vor egen Sag, om vi vil forfægte, som om vi vil fremsætte vore Betænkninger. Nu bliver det daglig meer min Overbeviisning, at hvor Sandheds Tro bliver levende, avler den altid $i$ sin Tid en tilsvarende Erkiendelse efter hvers Evne, Kundskab o.s.v., og at hvor Troen fattes, tvistes man forgiæves om Gienstande, der altid, efter Øiets Vilkaar, sees i forskielligt Lys, derfor vil jeg nu være seen til enhver Penne-Strid om min videnskabelige Syns-Maade, og hvor jeg seer, den enten er næsten ganske ubekiendt eller høilig miskiendt, der finder jeg mig forpligtet til ei at spilde Ord og Tid paa et unyttigt Forsvar, der ved den hartad uundgaaelige Heftighed, eller hvad vel end saarer mere, ved Ironie, rimeligvis end mere vilde forblinde. $\mathrm{Nu}$ fandt jeg i Deres Breve, at De ansaa mig deels for et meget uphilosophisk Hoved, deels for en Nar, der paastod, at der ikke var sagt et sandt Ord i det attende Aarhundrede, deels for en Velynder af det mechanisk-materialistiske Aabenbarings-System, som jeg altid har beleet, og af Almuens Ringeagt for Lære-Stand og Lærdom, som jeg altid har bestridt og om jeg da end nu var langt mindre utilbøielig til Penne-Strid om Sligt end jeg er, maatte jeg dog nødvendig finde, at her var det bedst at tie. Ansaae De mig nemlig for aldeles uskikket til at tale med om philosophiske Ting, da vilde min Tale derom paa Strid med Dem selv vist ikke omvende Dem, kiendte De ikke mine historiske Udtog og Dannevirke, da kunde De aldrig komme til at læse dem slettere, end naar de førtes i Marken mod Dem, og tiltroede De mig, efterat have læst mine Skrifter, den Synsmaade, jeg i dem har forkastet og bestridt, hvormed skulde jeg da be- // (2r) vise De tog Feil, eller afbevise den Beskyldning, at jeg i Afhandlingen om Natur og Aabenbaring modsagde mit nye System. Sandelig, her maatte jeg slutte: enten vil Doctor Faber nu engang miskiende, og, om han kan, nedrive dig som Skribent, og da lad det komme an derpaa om den der er $i$ ham eller den der er i din Skrift er den stærkeste, eller vores Menighed maa efterhaanden falde bort af sig selv, naar kun ikke en personlig Uvillie forhindrer det. De veed, jeg valgte den sidste Slutning, og da jeg først kom saavidt, vil De let indsee, jeg kunde offenlig forsvaret mig imod dem saa rolig og sagtmodig, at De $\mathrm{i}$ det Mindste vilde staaet som den Bittre og Fremfusende; men derved var vi næppe kommet hinanden nærmere, og sandelig, det er i vore Dage saa sjaldent at spore hos dem der skrive noget ret alvorligt, dem selv opfyldende Øiemed, at de der spore det hos hinanden, nødvendig maa ønske inderlig at enes, og føle den høieste Modbydelighed for at give hinanden til Priis, men da jeg indsaae det, kunde jeg ikke, uden at ville det, giøre Giengiæld, og Giengiæld vilde i Publicums Øine mit Forsvar dog altid været.

Men selv om jeg havde troet, at vor Feide, taget saa venlig, som jeg formodede, De dog i Grunden meende det, kunde vakt noget bedre end Galsen og Grin, saa forbød dog de nærværende Omstndigheder mig at optage Hand- 
sken; thi midt $i$ et Hoved-Slag ${ }^{22}$ ) maa man ikke modtage nogen Udfordring, uden i det Høieste paa Frist, og sandelig, naar vi har seet Udfaldet paa nærværende Slag, og De da end er af samme Tanker som nu, skal jeg slet ikke vægre mig ved en Dyst, skiøndt jeg vel mærker at Lysten dertil, naar man ellers vil noget Alvorligt, fragaaer med Aarene.

At De nu ikke er enig med mig i denne Tankegang, det, som sagt, veed jeg nok, men jeg vilde ogsaa kun vise, hvorledes det hængde sammen med min hele Tankegang, ei at indlade mig med Dem nu i en offentlig Strid om min Philosophering og Betragtning af det attende Aarhundrede, hvorom jeg i Øvrigt gierne privat skal besvare ethvert Spørgsmaal, De ønsker at høre mig om; thi hvad jeg har sagt, skal jeg enten kunne give skiellig Grund for, eller frafalde, det har altid været og skal bestandig være min Lov.

Men nu til den nærværende theologiske Strid, der er mig saa vigtig og Dem saa forargelig, og til Maanedsskriftet som jeg glæder mig ved, og som De slet ikke kan lide.

De angreb ikke min Tro og Theologie, skiøndt De dog ansaae Seiren for let, da De fandt det forargeligt, og den samme Tænkemaade skulde drive os til at undlade Angrebet paa Claussens, Hornemanns, Müllers o.s.v. Theorilagre, da Almuen derved kommer til at foragte Lærestanden og Bibelen selv, saa selvmodsigende. - Det er Deres Tankegang, men ikke vores, og jeg veed ikke, hvorledes det skulde blive min, der, vant til at betragte alt Menneskeligt historisk, klarlig seer, at Deres Tankegang har hele Historien imod sig. Hvad mener De saaledes, der vilde blevet af Reformationen, dersom Luther og hans Venner blot videnskabelig havde bestridt de falske Dogmer, uden at tale et Ord om Paven og hans Geistlighed som de der havde udruget og rugede over dem! At der ogsaa dengang mellem Geistlige var mangen ærlig Mand, der talde efter bedste Skiøn og ei fortjende at skiæres over een Kam med de lade Buge og Løgnhalse, det er jo upaatvivleligt, men, skulde man nu, for at ikke disse muelig skulde saares, eller ringeagtes, undladt den eneste Krigs-Brug der kunde nytte, og opstod derved en almindelig Foragt for Lærestanden, eller vaktes Folket ikke derved netop til at skiønne paa gode Lærere, naar de havde dem, og saa sig om bedre, naar de nærværende ikke duede, og er Det ikke hvad vi skal ønske! Hvem kan, som Sandhedens Ven, ønske falske eller vildfarende Lærere i Salighedens Sag mindste Gran af aandelig Agtelse og Tiltro, eller giøre sig mindste Samvittighed over at nedbryde hvad der holder Folket i Vildfarelse!

Dog, maaske er den nærværende Slægt saa sandhedskiærlig, saa aandelig vaagen, og saa aandelig bestemt at man blot behøver at bestride Vildfa // (3r) relserne i Almindelighed, for at baade Lærde og Læge, eller i det mindste de Første, vil tage alvorlig Deel i Undersøgelsen, og lade Sandhed giælde; saa $\mathrm{nu}$ er den polemiske Anvendelse paa Tid, Stand og Personer, som fordum fandtes nødvendig, aldeles overflødig, [] altsaa utilladelig, og fordi den baade forbittrer og vækker Ringeagt for det herskende Parti i Kirke og Skole, skadelig!

Tildeels er Dette sikkert Deres Mening, og da maa De nødvendig misbillige vor Adfærd, men hvad kan jeg for, at min Overbeviisning er lige den

$\left.{ }^{22}\right)$ Nemlig med professor H. N. Clausen. I »Kirkens Gienmæle« havde Grundtvig jo netop opfordret alle, som var enige om det »Grund-Christelige « til at forene sig og lade indbyrdes kiv fare, så fornuft-troen kunne blive besejret. (US IV, 418). 
modsatte, er den: at aldrig var det nødvendigere end nu, at angribe Tidens Vildfarelser med det det aabenbareste Hensyn paa den Tid, der avlede, den Stand, der udbredte, og de nærværende Mænd, der vedkiende sig dem. Sandelig tager jeg heri feil, da var denne Feiltagelse uundgaaelig, efter at have, som jeg, giennem en Række af Aar, seet Folk bestandig blive aandelig sløvere, meer og meer ligegyldige ved, hvad der sagdes mod deres System, naar kun deres Person blev i Fred, mere og mere ligegyldige ved, hvad der i Grunden var sundt, naar man kun havde Mad og Drikke og i det Høieste et Navn i den lærde Verden! De og jeg begriber ikke let, hvordan Præster og Videnskabsmænd kan tænke saa jammerlig; men kan De faae andet Resultat ud; naar De betragter ogsaa blot kun min Bane; thi hvem har reist sig til Forsvar af de Vildfarelser, jeg bekæmpede, snart i Almindelighed, snart som det attende Aarhundredes, snart som de Fremmedes, vi have efterlignet, eller hvad Tegn har man seet paa, at Folk derved vaktes til Eftertanke om, hvad der var Sandhed? Sandelig jeg har en god Samvittighed for, at have prøvet alt hvad jeg kunde, før jeg greb til det sidste Middel, der altid har mange Ubehageligheder i Følge med sig, // (3 v) det, personlig at angribe dem, der paa en eller anden Maade staae i Spidsen hos os for det uchristelige og aandløse Væsen, og sandelig naar disse endnu kun svare med Injurie-Processer og alskens Kneb til at binde Munde, da er det dog vel tilstrækkelig beviist, at dette Middel eller slet intet fører til Øiemedet! Desuagtet var det endnu min Grundsætning, saavidt som mueligt, at skaane Personerne, og den Undtagelse jeg har giort med Hornemann og Clausen var en tvungen Sag. De har Ret $\mathrm{i}$ at $\mathrm{H}$ ! aandelig talt, er høist ubetydelig; men naar det nu er sandt, at de theologiske Studenter tage sig langt anderledes af ham, end i Deres og mine Dage, naar de erklærer hans Lærdom for skriftmæssig, og Beviset for det Modsatte undertrykkes ${ }^{23}$ ), og naar han endelig for Kongen anklager en christelig Præst, som falsk $\operatorname{Lærer}^{24}$ ), da føler jeg, var Pligt at blotte ham. Clausen er de unge Studenters Orakel, paa hans Ord sværge de hartad uden Undtagelse, paa ham have de trodset ${ }^{25}$ ), som [paa] en Hører [0: lærer], der hvis nogen vovede at angribe hans Theologie, vilde lade sin høire Haand lære dem forfærdelige Ting, og naar nu han udgav en Bog, der nedbryder enhver tænkelig Fælles-Grund for den christelige Lære-Bygning, da maatte han nødvendig angribes paa det Djærveste, for at han enten kunde nødes til en Kamp, hvori man ikke maa tvivle om, jo Sandhed skal seire, eller tabe sit Helte-Navn, saa den Tanke fik Indgang, at han var dog nok langt fra at være ufeilbar.

Saameget om mine Skridt mod Personer, som jeg inderlig ønsker maatte være de sidste, naar Sagen taaler det, men hvis ikke, da faaer de i Guds Navn

${ }^{23}$ ) Hentyder til det forsvar for Hornemann, som hans tilhørere anonymt udgav januar 1825, samt til Jørgen Thisteds modskrift, der undertryktes af kancelliet, - se dette hæfte p.39. Grundtvig angreb Hornemann i Theol. Maanedsskr. I (juni 1825) p. $215 \mathrm{f}$.

${ }^{24}$ ) Hornemann havde i et skrift mod Thisted, der kun tryktes i fem exemplarer og bl. a. blev sendt til kongen (se dette hæfte p. 39) »påvist《, at kateketen Egge ved Fred. tyske Kirke førte en forkyndelse (om syndernes forladelse alene ved Jesu blod), som var farlig for »moraliteten« og dermed for staten. Det harmede Gr. voldsomt, og han angreb på det kraftigste Hornemann (Theol. Maanedsskr. III, p. 75 f.).

${ }^{25}$ ) i bet. »stole blindt på« (gl. sprog). 
blive saa mange de skal, og, hvad jeg aldrig kan frygte for, er at jeg skulde vakke Ringe-Agt for Lære-Stand og Videnskabelighed i det Hele; thi, alt Andet tilsidesat, saa er jeg jo selv Medlem af Lære-Standen og selv Videnskabs-Mand, og hvem der altsaa hører mig kan umuelig derved // (4 r) forledes til at ringeagte, hvad han agter $\mathrm{i}$ mig. Det eneste Tilfælde skulde være, hvis jeg, skiøndt selv Lærer, ringeagtede mit Embede og viste Forkiærlighed for Menig-Mands Conventikler, eller hvis jeg skiøndt selv Videnskabs-Mand ansaae det for en Ulykke, jeg for Eftertiden stræber at forebygge; men hvor vil man i mine Skrifter eller i min Virksomhed finde Spor af Sligt, eller hvor finder man ikke hos mig netop det Modsatte. Hvad jeg har arbeidet mod Pietismen og Sect-Væsenet baade i Danmark og Norge, det veed vistnok kun Secterne og jeg, men at jeg har bestridt det i mine Skrifter kan dog alle $s^{26}{ }^{26}$, og visselig, da jeg i syv $A a r^{27}$ ) lod det herskende Partie spærre Kirken for mig, uden i dette Tidsrum enten mundtlig eller skriftlig at bestride den usle Theologie, der var bange for min Modsigelse, da viste jeg dog vel, hvor vigtigt det var mig, at Reformationen ei skulde begynde i Krogene paa Strid med Lærer-Standen i det Hele. At desuagtet nu, som ved den forrige Reformation (!), Endeel af Kampen mod den i Standen herskende Lunkenhed, Aandløshed og Vantro, tage Anledning til at foragte Standen i det Hele, kan vistnok ikke omtvivles, men det er aabenbar et langt mindre Onde, end om Folket blev i den Dorskhed, hvori efter min Overbevisning og Erfaring, Mængden af Præsterne daglig mere rodfæester dem. - De vil maaskee mene, jeg dømmer for haardt, ved at sige Mrngden, men mit Levnets-Løb og mangehaande Forbindelser har i en Række af 25 Aar lært mig at kiende mere til Landets Geistlighed end de Fleste, og efter min egen Overbevisning maa jeg tale og handle. - Man maatte græde Blod, naar man er Vidne til, hvorledes Præste-Embedet nu almindelig forrettes, thi det kunde ei skee aandløsere og skiødesløsere i det mørkeste Pavedom, og en saadan Præste-[Folk] Flok skulde man ønske Folkets // (4 v) Agtelse og Tillid (naturligvis i aandelig, ei i borgerlig Forstand) dem skulde man endog bede Øvrigheden med Magt beskytte i LæreMonopolet $!^{28}$ ) Nei, nei, det kan ikke være Deres Mening, De veed ikke, hvordan Præsterne sædvanlig er, ellers vilde De vist være enig med mig om, at her er Intet at skaane, da de hæderlige Undtagelser sikkerlig ei vil blive mindre, men netop mere bemærkede af Folket, naar dets Øine oplades.

Hvad nu Maaneds-Skriftet i det Hele angaaer, da forudsætter De, at jeg billiger Alt, hvad deri findes, og at vi staae i den Vildfarelse, at ikke Vantro og Verdslighed i det Hele har aulet Foragten for christelig Tro, men Denne derimod hine.

Først maa jeg herved anmærke, at skiøndt jeg staaer paa Titelbladet som Medudgiver, er jeg dog kun simpel Medarbeider af Mskt, og vil ikke være andet, befatter mig ikke med Redactionen, og har kun gjort [til] een Betingelse for min Medvirkning: at Intet indføres som strider mod Bibel og christelig Tro, overladende i øvrigt til hver Medarbeider og til Redacteuren, Doctor Rudelbach at følge sit Hoved, som jeg følger mit. Mit Navn har jeg kun givet

${ }^{28}$ ) Cf. Grundtvigs omtale af f. eks. de pietistiske og herrnhutiske gudelige forsamlinger $\mathbf{i}$ »Verdens Krønike« 1812, US II, p. $296 \mathrm{ff}$. og $302 \mathrm{f}$. og artiklen »Om gudelige Forsamlinger, Nyeste Skilderie af Kjøbenhavn« $8 / 21825$.

${ }^{27}$ ) 1813-1821 var Grundtvig uden præstekald.

${ }^{28}$ ) Nl. ved at forbyde gudelige forsamlinger. 
til et Pant for mit Publicum, om jeg har noget, paa Retningen af det Hele og paa min flittige Medvirkning, da man troede, det under den nærværende BogSky var nødvendigt for at Skriftet kunde udkomme. Om jeg ogsaa kunde, vilde jeg dog ingenlunde beherske Tonen og Yttringerne i dette Skrift, thi det er netop min Glæde derved, at jeg ikke har skabt det, at det er en reen, fri Yttring af den theologiske Opposition i Landet, hvad det ophørte at være, saasnart jeg eller nogen Enkelt beskar det efter sin Læst. Jeg har i flere Aar, under [] inderlig Sorg over den voxende Sløvhed og Dorskhed, der gjorde Litteraturen aldeles til en øde Mark, ønsket et saadant Maanedsskrift, men fundet, deels at jeg hverken havde Stunder eller Duelighed til at redigere det, og deels, at efter min Erfaring, var min Stemme unyttig, naar den blev ene. Det maatte derfor nødvendig // (5r) glæde mig som en Guds Styrelse, og et ønskeligt Tidens Tegn, da et Selskab af yngre $M_{2} d^{29}$ ) indbød mig til Medvirkning, og sandelig, jeg vilde glædet mig, om der enda ikke blandt Dem havde været en saa erudit Theolog, som Rudelbach, og saa god en Orientalist, som Lindberg, [som s] selv efter Modstandernes Dom, unægtelig er. At Mænd, der egenlig først her betræde Skribent-Banen, og det den Polemiske, ei skulde snuble, og at Alt hvad der findes $i$ et Maanedsskrift skulde være lige omhyggeligt giennemtænkt og udarbeidet, var saa urimelig en Fordring, at De vist ligesaalidt som jeg vilde giøre den, og saalænge vi ei har et bedre oppenerende Tidsskrift er, efter min Overbevisning, selv det middelmaadigste langt bedre end slet intet. Om nu Nogen af Medarbeiderne skulde staae i den vrange Formening, at man havde begyndt at foragte Christendommen, medens man endnu var i Grunden religjøs og aandelig, saa at naar kun en vis Frbødighed for det christelige System kom tilbage, fulgte Resten af sig selv, det veed jeg ikke vist; men at det er langt fra min Mening, synes mig allerede min første Betragtning i Mskt. maatte sige alle Læserne, og mine Skrifter er desuden fulde af Yttringer, som ei skulde lade Nogen tiltroe mig en ligesaa aandløs, som uhistorisk Betragtning af Tidens Elendighed og Midlerne derimod. Deri er vi to da ingenlunde uenige, men vel om den christelige Troes Væen og Kraft; thi naar jeg taler om den eenfoldige Barne-Tro, som ene gør salig, og hvoraf alt christelig Godt og Stort udspringer, da mener jeg en levende Kilde i Menneskets Inderste, hvis Kraft jeg kiender hos mig selv og sporer i Historien, men De tænker, jeg taler om en død historisk Tro, et livløst Bifald af endeel forunderlige Sætninger, som Lidet eller Intet har med Menneskets aandelige Natur og inderste Væen at giøre, paa en saadan Skabilken-Tro anvender De nu de Prædikanter jeg giver Troen, og finder naturligviis, de er upassende, og her er Nøglen til vor egenlige Uenighed. Denne Uenighed // (5v) kan Gud kun hæve, og hæves den ikke, da bliver vi heller aldrig theologisk enige; men De vil vist indrømme, at naar jeg virkelig kiender Troen fra en saadan velsignet herlig Side, maa jeg nødvendig sætte den høit over al menneskelig Viden, og ansee den for Tidens store Savn, paa hvis Oprettelse det i Grunden ene lønner Umagen med Gud at arbeide, da en saadan Tro er, hvad Alle for Tid og Evighed behøve, og er tillige Kilden til al sand Videnskab og Erkiendelse. At det uden saadan levende Tro kan omtrent være det Samme, hvad System man følger, giver jeg Dem Ret i; og har i min Historie, bestandig indskærpet

$\left.{ }^{29}\right)$ Rudelbach, Lindberg, J. A. L. Holm, P. A. Fenger og C. de Thurah, der imidlertid sommeren 1825 blev præst i Ribe. De leverede alle stof til de første numre af Theologisk Maanedsskrift. 
det, men jeg kunde dog ikke tro paa et Guds Ord i Skriften ${ }^{30}$ ), naar jeg tænkde, det ogsaa for Menigheden var ligegyldigt, om Præsterne uden levende Tro forkyndte det Ord, eller deres eget derimod stridende, eller dog tomme og vandede; thi Guds Ord maa nødvendig selv fra de koldeste Laber, naar det kun prædikes som Sandhed, plante Troen i aabne Barne-Hjerter og nære den hos de Troende.

At man imidlertid ikke ved at sige, hvad Fædrene troede kan drive vantro Præster til at forkynde Guds Ord, er ganske rigtigt, men naar Folket er sovet ind ved den Tanke, at de troede Guds Ord som Luther, kan det dog vel vække dem til Eftertanke at høre, hvad Luther troede, og naar de seneste Theologer har paastaaet, at i Grunden var Luther og alle fornuftige, boglærde Folk enige med dem om, hvad de kaldte Christendom, er det vist nødvendigt, at man lærer, det er ikke sandt; thi før spørger man sikkert ei alvorlig: hvad er da sandt? og før man spørger saa, kommer man bestemt hverken til Sandhed, Tro eller Erkiændelse. Med en saadan Oplysning maatte derfor, efter min Overbevisning, Oppositionen begynde, men vistnok ikke ende, og det vilde, efter min Tanke, være begyndt, at bygge nye Huse, før Folk begyndte at føle, de kunde behøves. - Om Forargelsen det giver at nedrive har jeg strax i Mskt. sagt mine Tanker ${ }^{31}$ ), og er det dog ikke sandt, at har // (6r) man i det attende Aarhundrede først givet den Forargelse at rive Templet ned og bygge en Moske isteden, kan Templets Venner sagtens forsvare Forargelse, det skal kunne give i det Nittende at rive Moskeen ned, da det er en nødvendig Forberedelse til Templets Gien-Opbyggelse.

Derfor er Lindbergs lunefulde Opregnelse af Orientalisternes bibelske Fortjenester netop et af de Stykker i Mskt. jeg inderlig glæder mig over, thi hvad Forskiel, der end kan være og bør taales for christelige Theologer paa Vurderingen af det Gl. Testamente, er det dog vist, at det bliver aldrig enten christelig lært eller ordenlig forstaaet, før man finder hin splittergale Behandling deraf ligesaa latterlig, som harmelig. Citationerne er ogsaa nødvendige, thi, uden dem vilde man sige, L. kæmpede med sin egen Skygge, og de Mænd, det Gl. Testamente har maattet lade sig mishandle af de eller deres Maner ( 0 : onde ånder) maae ogsaa finde sig $i$, at Testamentet hævner sig ved sine Venner. Betænker man derhos, at Hornemann har i 50 Aar været vor eneste theologiske Orientalist ${ }^{32}$ ), da mener jeg, en saadan Udstilling af deres Latterlighed, der vilde giøre Skriften latterlig, er aldeles nødvendig.

Overalt, kiære Ven! det er en egen Sag at føre Krig i Ordets saavelsom i Kroppens Verden, og det læres kun ved Øvelse. Enhver unødvendig Krig er i begge Verdner uretfærdig; men skal der være Krig, da maa man tage sit

30) Det er bemærkelsesværdigt, at dette er skrevet i december 1825 . Grundtvigs syn på skriften som »kun« en oplysningskilde og på den apostolske trosbekendelse som »Herrens ord« til os, mærkes der intet til i brevet, tiltrods for, at den mageløse opdagelse var gjort $i$ juli. Det er et vidnesbyrd om, at 》opdagelsen « ikke slog igennem med det samme, men først fandt egentlig skikkelse i de følgende år. I 1825 var trosbekendelsen først og fremmest kampvåbenet.

31) Theologisk Maanedsskrift I, $35 \mathrm{ff}$.

${ }^{32}$ ) J. Rasmussen beskæftigede sig ikke med den teologiske side af GT-forskningen, udgav $i$ alt fald intet derom. Jens Moller, som også forelæste over GT, ydede heller intet synderligt på dette felt. Det samme gælder biskop Fr. Münter. 
Partie, og aldrig glemme, at Krig er ikke Fred, og at der følge mange Ting med Krigen, som man maatte ønske, kunde undgaaes, og som man selv skal tage sig i Agt for at øve, tilraade eller billige, man maae nødvendig ogsaa vogte sig for med Magt at ville forhindre eller straffe, hvis man ikke derved vil give Fienden Spillet vundet. Det varede længe, inden jeg kunde lære denne simple Klogskab, skiøndt den indskiærpes paa hvert Blad i Aandens Historie, jeg vilde ingen Medhjælpere have, med hvem jeg ikke var fuldelig enig baade om Sagen og Fremgangs-Maaden, og for at vise min Upartiskhed, lastede jeg ligesaa ivrig Vennernes Feil og Mangler, som Fiendernes Udaad, hvorpaa mine Skrifter kun give alt for mange // $(6 \mathrm{v})$ Beviser, men Følgen var naturligvis, at den, hvis Haand var mod alle, fik alle Hænder mod sig, og der udrettedes Intet. $\mathrm{Nu}$ har, troer jeg, baade Kiærlighed og Klogskab lært mig, det var galt, og jeg troer, de vil engang lære Dem det Samme, og fremforalt bevare Dem for den Mynsterske Tactik, at spilde Sagtmodigheden paa Fienderne, og vise en Tapperhed paa Vennerne $!^{33}$ ) Er vi enige om, at der var indbrudt en Vinter i Kirken, en Sløvhed og aandelig Dorskhed i Lærestanden og hos Folk i det Hele, som maa bestrides og med Guds Hjelp fordrives, da lad os stride hver efter bedste Skiøn, uden at bestride hinanden, før vi i det mindste har vundet Hoved-Slaget, thi før er det for tidlig at kives om Byttet, det leer kun Fienden ad. Kun dem der vil bruge verdslige Vaaben $\mathrm{i}$ aandelig Strid $^{34}$ ) og dem der bære Kappen paa begge Skuldre ${ }^{35}$ ), kun dem vil jeg skille mig fra, og for Resten, med Guds Hjelp, taale Alt hvad der kun rammer min Personlighed og Skribent-Carakteren, eller kun støder min særegne Følelse og Tankegang, altid raade til hvad jeg anseer for bedst, og fraraade hvad jeg misbilliger, men ei derfor fare i Harnisk. Kan vi ikke enes om, at Det er i Krigen det Rette, da blive vi, saalænge Krigen varer, ikke gode Venner; men kan vi enes derom, da bliver vi i det mindste Venner under Krigen, og siden har det vel, med Guds Hjelp, ingen Nød; jeg har i det mindste hidtil, Gud skee Lov! ingen Venner mistet i Freds-Tid. Og sandelig, vil De kun ikke overile Deres Dom efter hvad der maa skee, for at afnøde Fienden et Slag i aaben [bar] Mark, skal De vist ikke finde mig for krigersk stemt; thi jeg gik denne Gang i Marken, ei fordi det var min Lyst, men fordi jeg klarlig saae, det var min Pligt, og der er sikkert Ingen af de Krigsførende, der længes mere efter Freden, end jeg, men at slutte Fred paa Krigens Bekostning, derfra bevare mig Gud, hvad der saa end skal times; thi jeg veed, paa Hvem jeg tror! Dog, Brevet er blevet saa langt, som jeg kun for en halvsnes Aar siden pleiede at skrive, og jeg vil da slutte med den Erklæring, at skiøndt jeg nuomstunder næsten aldrig skriver Breve, giør jeg med Fornøielse en Undtagelse her, naar De kan finde Dem ligesaa godt i min Skrive-Maade, som jeg finder mig i Deres.

\section{Venligst Grundtvig.}

$\left.{ }^{33}\right)$ J. P. Mynster udgav i oktober sin prædiken »Den christelige Viisdom《, som Grundtvig her hentyder til, hvor han - med tydelig henblik på Gr. og hans venner - udtrykte forargelse over deres polemik. Gr. svarede den følgende søndag med prædikenen $\gg D e n$ kristelige Kamp«.

${ }^{34}$ ) Clausen havde anlagt injuriesag i stedet for at tage handsken op. På den anden side kan det ikke overses, at Grundtvig selv i »Kirkens Gienmæle« (således i fortalen) antydede, at Clausen havde overtrådt de danske kirkelove, og i 1826 udsendte han »Vigtige Spørgsmaal«, som klart giver udtryk for den »juristiserende tendens«.

35) J. P. Mynster, Jens Møller m. fl. Cf. også det tidl. citerede brev af Münter. 